\title{
CONTRIBUTION TO THE LIFE HISTORY AND PHYSIOLOGY OF CYLINDRO- SPORIUM ON STONE FRUITS
}

\section{A THESIS}

Presented to the Faculty of the Graduate School of CORnell University FOR THE DEgree oF DOCTOR OF PHILOSOPHY

$$
\text { BI }
$$

BASCOMBE BRITT HIGGINS

\footnotetext{
Reprinted from AMERICAN JourNal OF BotaNY, 1: I45-I73. April, I9I4.
} 



\section{CONTRIBUTION TO THE LIFE HISTORY AND PHYSIOLOGY OF CYLINDRO- SPORIUM ON STONE FRUITS}

\section{A THESIS}

Presented to the Faculty of the Graduate School of Cornell University for the Degree of DOCTOR OF PHILOSOPHY

BY

BASCOMBE BRIT'T HIGGINS

Reprinted from American Journal of Botany, 1: 145-I73. April, igi4. 
SB741

$\mathrm{C}_{96} \mathrm{H}_{5}$

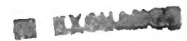

UL 9 ?14 


\title{
CONTRIBUTION TO THE LIFE HISTORY AND PHYSIOLOGY OF CYLINDROSPORIUM ON STONE FRUITS ${ }^{1}$
}

\author{
Bascombe Britt Higgins \\ With PLATES XIII-XVI
}

INTRODUCTION.

The disease of plums and cherries caused by the fungus Cylindrosporium has long been known, and because of its economic importance and peculiar appearance has for many years attracted the attention of horticulturists and plant pathologists both in Europe and America. On certain species of the hosts the disease becomes very conspicuous because of the "shot hole" effect on the leaves, produced by the dropping out of roundish areas of diseased tissue. From the leaves of other species however the spots do not drop out, and usually in such cases the leaf tissue is not killed to any appreciable extent. In casies of severe attack the leaves often turn yellow and drop prematurely, which of course interferes more or less seriously with food production and the future welfare of the tree.

"Shot holes" are produced in the leaves of stone fruits by several different organisms or even by mechanical injury, for example, as the result of a needle prick. Duggar (8) found also that they were produced readily by spraying plants with poisonous solutions. However, the fungus Cylindrosporium is probably the most prolific cause of this phenomenon, at least in cherries; and many collectors have apparently attributed all "shot hole" effects on species of Prunus to Cylindrosporium padi Karst.

${ }^{1}$ Contribution from the Department of Botany, Cornell University. No. 155.

[The JoukNAL for March (1: 97-144) was issued 6 May 1914.] 
This fungus was described by Karsten (I7) in I 884 from leaves of Prunus padus; and Sorauer (13) states that in Europe the disease is confined almost entirely to this species. Aderholdt (I) in I90I said that the disease had been common on both sweet and sour cherries during the previous ten years. In America a disease attributed to this organism has been reported on nearly all species of Prunus both wild and cultivated.

Because of the prevalence of the disease and its consequent economic importance, it has seemed very desirable to know the complete life history of the fungus causing it. With this purpose in view an investigation has been in progress during the past three years, the results of which are here reported.

For several years the disease has been very abundant in the vicinity of Ithaca, New York, on the sweet cherry $(P$. avium) and the wild choke cherry ( $P$. virginiana). It has been found less abundant on the sour cherry ( $P$. cerasus, $P$. mahaleb, $P$. pennsylvanica), and on the plums ( $P$. domestica, $P$. insititia, and $P$. spinosa). Through the courtesy of Professor J. G. Hall (now of Pullman, Washington) leaves of $P$. serotina affected with the disease were obtained from Clemson College, South Carolina, in August, I9I2. A Septoria having spores only slightly different, but produced in a pycnidium, also found on $P$. pennsylvanica, was studied for comparison with these. The results of this study of Septoria will be reported in another paper.

This abundance of material on a number of host species has made possible a comparative study of structural characters, relation to the host tissue, cultural characters, interrelations of the fungus on the different hosts, and its life history. Pure cultures of the organism from $P$. spinosa were not obtained, so that it could not be included in all the comparisons.

\section{Structural Characters}

The genus Cylindrosporium is characterized by having elongated colorless conidia borne on a more or less disk-shaped stroma just beneath the host epidermis. The acervuli on all the species of Prunus under observation agree with this characterization. The stroma is very delicate, at first consisting of one cell layer only, but becomes slightly thicker as the acervulus grows older. On the outer surface of this stroma short conidiophores give rise to conidia. They develop first over the center of the stroma and continue to develop centri- 
fugally as the latter grows in diameter. This growth of the stroma is lateral, extending out between the epidermis and mesophyll of the leaf, and never turns up at the edges so as to resemble a pycnidial structure. $^{2}$ The stroma which bears conidia lies under the epidermis on either surface of the leaf. When the conidia have accumulated in sufficient number the epidermis is broken and they appear usually as a whitish or yellowish white mass above the stroma. In $P$. serotina (more rarely in other species) the stiff cuticle prevents the formation of a large opening and the conidia are forced out in long tendrils. ${ }^{3}$

The conidia from all the host species are very similar. They are long, slender, curved or flexuous, and continuous or $\mathrm{I}-3$ septate. ${ }^{4}$ There are a few minor differences which are not very distinct, since the conidia vary considerably on each host. The conidia from plum leaves (all three species) were more constant than those from cherry leaves. Here they are blunt at the proximal end and taper gradually toward the apex, and they are mostly once septate. The largest spores found were from $P$. serotina and $P$. virginiana. On both species spores measuring $45^{-80} \mu$ in length were found. On no other species were they found as long as $80 \mu$.

${ }^{2}$ Septoria cerasina Peck (29th Report N. Y. State Mus. Nat. Hist. 48, I878) the type material of which, through the kindness of Dr. Peck, I have had an opportunity of examining, has a typical fruiting structure of this description (fig. 4). The same is true of the specimen distributed in "Fungi Americana" No. 747 as Septoria Ravenellii Thüm, which is apparently identical with S. cerasina Peck. This is not the case, however, with Septoria pruni Ellis, which Aderholdt (I) includes as a synomym of Cylindrosporium padi Karst. Here a distinct pycnidial structure surrounds the spores which shows it to be a true Septoria. This was not from type material, but from the specimen in Ellis' North America Fungi II5I in the Cornell University herbarium. It is from the same collection which Aderholdt must have examined, though of course in such a large collection some leaves affected with Cylindrosporium might also be included.

${ }^{3}$ This accounts for Peck's (23) statement that $S$. cerasina differs from Cylindrosporium padi (on $P$. domestica) in this character.

${ }^{4}$ Aderholdt (I) says that the conidia are not truly septate but have false cross walls. He does not state how this was demonstrated. Pammel (22) says that the cross walls react to stains in exactly the same way that the side walls react, and this has been confirmed by my own studies. Haidenhain's iron alum haematoxylin Delafield's haematoxylin, and Flemming's triple stain all bring out the cross walls very distinctly. Very often also the cells become constricted at the cross walls upon germination; or the contents of one cell may be lost entirely without apparently affecting the rest of the conidium. 


\section{Cultural Characters}

The conidia seem to lose their vitality very rapidly on drying. When they are taken from the dry masses which cover the acervuli only a small per cent of them germinate in nutrient agar or in tap water; and some taken from cherry leaves which had not been wet for about a month failed to produce infection on other leaves of the same plants.

Fresh spores germinate very slowly in agar. For this reason and because of the large number which failed to germinate it was found very difficult to obtain pure cultures of the fungus by the dilution method. When leaves were placed in a moist chamber for a few hours so that fresh conidia were formed, pure cultures were readily obtained by picking up a quantity of them on the point of a needle and then dragging the needle across an agar plate. After four or five days there were usually spots on some of the streaks free from bacteria and other fungi where some of the Cylindrosporium conidia were beginning to germinate. Blocks of agar containing such germinating conidia were then transferred to tubes of agar or to sterilized bean pods.

Comparison of the fungus isolated from the different hosts was made chiefly from growth on steamed bean pods; but the nature of the medium seemed to have very little effect on the nature of the growth, colonies very similar to those on bean pods being produced on agar dissolved in tap water; on agar to which had been added an extract of beans, potatoes, malt extract, prunes, or cherry leaves; on sterile slices of pear; or on steamed cherry leaves.

Growth from the spores is always very slow, and is usually not apparent to the unaided eye until IO-I5 days have passed. At this time it appears as a small whitish speck, which when examined microscopically is found to consist chiefly of a stroma covered with quantities of conidia similar to those produced on the host plant. This stroma grows slowly, enlarging until a hemispherical mass $0.5^{-I}$ $\mathrm{cm}$. in diameter is formed, which occurs in about two months. Before this time the stroma has turned coal black and has a carbonaceous, crust-like appearance in the fungus isolated from $P$. domestica and $P$. insititia. After the stroma has turned black few spores are produced even when transferred to new media. The stroma produced from the fungus isolated from $P$. avium, $P$. cerasus, and $P$. pennsylvanica sometimes turns dark but never black and crust-like as in that from the plums. The stroma from the other three cherries, $P$. virginiana, $P$. 
serotina, and $P$. mahaleb, has never been observed to turn black and has usually a creamy white and more floccose appearance.

\section{Relation between Fungus and Host}

Interest in the physiological relation between the fungus and the host tissue was aroused by the observation, before mentioned, that the spots containing Cylindrosporium are deciduous in some species while in others they are persistent. Even in the same species there is marked variation in this respect. This variation is very striking in $P$. virginiana where ragged remnants of leaves, from which dozens of spots have dropped out, may later be abundantly infected with apparently little injury to the leaf tissue except the killing of a few cells in immediate contact with the acervulus. Because of this marked variation as host, $P$. virginiana was used chiefly in this part of the investigation which was undertaken in the hope of finding some explanation for this phenomenon.

The first problem was to find, by a histological study, what occurs just before and at the time of the dropping of the spots. For this purpose a series of spots were cut out so as to include some of the surrounding healthy tissue. These were killed, embedded in paraffin, and sectioned. The series began with the first sign of infection (a slight yellowing of the leaves) and included all visible changes until after the spots had fallen. After sectioning, several stains were tried. Durand's (9) method for differentiating mycelium of parasitic fungi worked very well, and was used where it was desired to see the position and extent of the mycelium.

The mycelium is intercellular, with haustoria which penetrate the host cells (figs. I 7, I 8). The haustorium enters through a very small hole in the cell wall and is very much attenuated as it enters, but the end enlarges into an oval or elliptical body which contains a nucleus and a comparatively large vacuole. After the haustorium has entered, the protoplasm of the invaded cell often deposits a cellulose sheath around the haustorium, apparently similar to that formed around the haustoria of the Erysiphaceae as described by Smith (25). This sheath often extends along the wall of the host cell for some distance also.

The host cells are not killed at first except those in contact with the stroma; and their death is probably brought about by drying rather than as a result of any toxic secretion from the fungus proto- 
plasm. That no very poisonous toxin or enzyme is given off is indicated by the fact that cells penetrated by the haustoria appear healthy and are able to deposit a cellulose sheath around the haustorium.

In every case examined acervuli had already formed and had broken the epidermis of the leaf, more commonly on the upper surface, but often on both surfaces. In every case also, even the very earliest, the tissue of the spot containing the fungus had already separated or begun to separate from the surrounding tissue.

Formation of Absciss Layer Around the Spots.-This separation is brought about by the enlargement of a layer of cells at some distance from the ends of the mycelium (figs. I4, I5, I6). Their enlargement is so abrupt and so great that the active cells separate from the adjoining inactive cells inside. The enlarged cells have lost their chloroplastids and nuclei, and only a thin layer of protoplasm lines the wall. The loss of the chloroplastids causes the watery appearance of this ring of tissue which was noted by Duggar (8). The tendency for the formation of this layer to follow the veinlets of the leaf as mentioned by this author has very rarely been noticed. The spots which drop out are usually very nearly round; and, even when quite irregular, the margin is evenly curved and smooth, not angular as it would be if the separation was limited by the veinlets.

After the separation is completed all around, the spot turns yellow, shrivels rapidly and soon drops out. Sometimes (often in $P$. serotina) the tension exerted by the enlarging cells is not sufficient to rupture the cuticle, but the cellular tissues are ruptured and the spot dries but remains in position. After the separation has occurred a layer of cells just outside the enlarged cells shrivel, forming additional protection for the healthy tissue.

In order to obtain the earlier stages of the process, plants in the greenhouse were inoculated with fresh conidia from leaves of $P$. virginiana which had been inoculated with a pure culture from the same species. The conidia were placed in a drop of water on a glass slide and a little powdered chalk added for the purpose of marking the inoculated spots. Small droplets of this water containing spores and chalk were placed on the under surface of the leaves of two plants and on the upper surface of two, and all four plants covered with bell jars. After three days some of the inoculated spots were cut out, killed in hot (about $60^{\circ}$ C.) chrom-acetic acid, and embedded in paraffin. This was repeated every 24 hours until acervuli appeared above the 
chalky spots on the sixth day. Infection did not occur in any case where the spores were placed on the upper surface of the leaves.

When this paraffined material was cut and stained no mycelium was found within the leaf tissue killed the third day. By the end of the fourth day some germ tubes had entered and had formed quite extensive mycelium. When these mycelial threads, entering the stomates of the lower epidermis and traversing the mesophyll, come in contact with the upper epidermis they branch profusely and form by the end of the fifth day a very delicate stroma with conidiophores and young conidia. By the end of the sixth day conidia have matured in sufficient numbers so that the pressure ruptures the leaf epidermis above the stroma.

No haustoria were found until the fifth day. The host cells appear normal until the sixth day, when, in a few cells just beneath the stroma and in contact with it, the protoplasm was slightly shrunken, due probably to drying. This appearance spreads rather rapidly after the epidermis is broken. The leaf tissue containing the fungus is separated off by the enlargement of certain cells mentioned above and the separated tissue yellows rapidly. The length of time varies, but usually within 7 -Io days after infection the spots begin to yellow and drop out.

An apparently related case to this shedding of the diseased spots is that reported by Galloway (12) in which the needles of Pinus virginiana drop off after the formation of Coleosporium pustules. Galloway says that this casting is not caused by the fungus directly but by the loss of water through the break in the epidermis.

Enlargement of Cells of Absciss Layer. - To explain the enlargement of the cells of the separation layer, four hypotheses have been suggested, viz.: First, the release of tension due to shrinking of the adjoining cells may allow the cells to enlarge; second, the cell walls may be softened by some enzyme secreted either by the fungus or by the host protoplasm, thus allowing the cells to expand; third, the colloids of the cell (protoplasm, cell wall, etc.) may be so modified as to have a greater affinity for water; and fourth, the osmotic pressure may in some way be increased in these cells. Of the four the last seems to be the most plausible, and while it is not yet proven beyond doubt all observations seem to support this as an explanation for the phenomenon.

The first hypothesis is invalid because these cells begin to enlarge 
before the adjoining cells have shrunken to any appreciable extent. Further the cells of these leaves do not enlarge to any appreciable extent, if the tension is removed entirely by cutting or tearing the leaf or if the tissue is macerated and the cells set free in water.

The second hypothesis does not appear valid, since if such an enzyme were secreted it would probably spread to adjacent cells. Also it is not very likely that, with the loss of water from the adjacent cells and consequently to some extent from these, the internal pressure would be great enough to expand the cells very much. At least with only ordinary osmotic pressure to hold the cell water, the cells would quickly collapse on exposure to the air.

The third hypothesis is similar to that held by Fischer (Io) to be the cause of oedema in animals, where the swelling is said to be due to modifications in the fibrin of the blood, muscle, etc. At first the disappearance of the plastids and nuclei seemed to argue in favor of this hypothesis, but when the stained sections were examined again the interior of the cells was found to be colorless while the protoplasm lining the cell wall was stained and distinct, which indicates that the interior is filled with cell sap.

That osmotic pressure is capable of causing the enlargement of plant cells is shown by the development of intumescences under various conditions during which increased osmotic pressure in the cells occurs. The question is then, how can the increased pressure be brought about in this case.

Production of Shot Holes Correlated with Amygdalin Content of Leaves,-Observations seem to indicate that the shedding of the diseased spots is correlated with the amygdalin content of the leaves. As before mentioned the spots are shed from $P$. virginiana during all the spring and early summer. Morse and Howard (20) have shown that the young leaves of this species are very rich in amygdalin which diminishes in amount with the age and vigor of the leaves. Of the species under observation, the following also shed the spots infected by Cylindrosporium while the leaves are young: $P$. serotina, $P$. pennsylvanica, $P$. cerasus and less frequently $P$. domestica. They are never shed from leaves of $P$. mahaleb, $P$. spinosa (not seen infected while leaves were very young) and, except under rare conditions, from $P$. avium. According to publications summarized by Wehmer (30), amygdalin is found in the leaves of $P$. virginiana, $P$. pennsylvanica, $P$. serotina, $P$. cerasus (?) and in young but not in mature leaves of $P$. domestica. It is not found in $P$. mahaleb, $P$. spinosa, or $P$. avium. 
It has been found that leaves which contain amygdalin produce also an enzyme, emulsin, which, under certain conditions, breaks the amygdalin down into benzoic aldehyde, hydrocyanic acid and glucose.

Morse and Howard (20) found that wilted cherry leaves yielded much more prussic acid than fresh leaves, but offer no explanation as to why the leaves should do so.

More recently H. E. and E. F. Armstrong (2), in an interesting paper on "The origin of osmotic effects," find that prussic acid is set free in the leaves of the cherry laurel by treating the leaves with vapors of anaesthetics, with alcohols, or many other organic and inorganic compounds which enter the cells of the leaves. The authors think that when these substances enter the cells they change the osmotic relations in the cell, and enzymes are set free which break down the hydrolites stored there.

Guignard (I4), who has done much work on emulsin and cyanogenesis, found emulsin in the endodermis of the vascular bundles only in leaves of $P$. laurocerasus. He suggests that wilting, action of chemicals, anaesthesis, or anything which alters the osmotic relations of the cells would bring the emulsin and hydrolite together.

Mann (I9) ${ }^{5}$ states that, in curing certain grades of tea, leaves allowed to wilt slowly increase the amount of the enzymes which break down the objectionable compounds. He thinks that these enzymes are not present as such, but zymogens are present which break down and form enzymes when the leaves wilt.

Green (I3) thinks that in many of the plants enzyme antecedents exist first as zymogens, and in a few instances has shown rather definitely that such is the case.

It is quite possible that the emulsin zymogen exists, along with amygdalin in the cells of cherry leaves, and that the enzyme is set free by slight changes in the osmotic pressure in the cell. Should this be the case certain observed phenomena (e. g., the rapid splitting of amygdalin in wilted leaves) could be more readily understood.

In whatever condition the enzyme exists, in cherry leaves it seems certain that it comes in contact with and breaks down the amygdalin when the leaf tissue wilts; and with this fact in mind a very plausible theory of "shot hole" formation can be formulated. When the acervuli and spores of Cylindrosporium break the leaf epidermis, the

${ }^{5}$ Original paper not seen but only a summary in Fowler's "Bacteriological and Enzyme Chemistry." 
underlying cells dry out rapidly. As the wilting spreads the amygdalin comes in some way in contact with the emulsin and is broken down. Each molecule of amygdalin breaks down into four molecules (one each of hydrocyanic acid and benzaldehyde and two of glucose), thus materially increasing the osmotic pressure in the cells where this occurs. The increased osmotic pressure enables them to draw water from the adjoining cells and swell until this pressure is more nearly equalized.

Since HCN has been found to increase the activity of proteolytic enzymes, it is quite probable that its presence in the enlarging cells causes the digestion of the plastids. Butkewitsch (7) found that addition of $\mathrm{HCN}$ accelerated the self digestion of the proteins in crushed seeds of several plants. Vines (29) also noted this property of HCN and suggested that its function in seeds might be to facilitate proteolysis of the reserve materials on germination.

Amygdalin Removed from Area of Leaf Occupied by the Mycelium. -One question which naturally arises is, Why is this separation layer always formed at such a distance from the acervulus as to include the fungus mycelium? This question is readily answered according to the previously discussed theory, if the fungus is capable of using amygdalin as a food; since in that case the amygdalin from the cells in the immediate neighborhood of the mycelium would be absorbed by it. The separation layer would then be formed by the cells outside this region, the amygdalin of these cells breaking down and producing the necessary osmotic pressure. The fungus could certainly use a part of the amygdalin molecule (e. g., the sugar), if it contains an enzyme to split the amygdalin into these simpler compounds.

To test this hypothesis, several cultures of the fungus from $P$. virginiana, $P$. mahaleb, $P$. pennsylvanica, and $P$. avium all growing on sterilized bean pods were used. From four cultures the liquid in the bottom of the tube was filtered off and a quantity of absolute alcohol added to the filtrate. A flocculent precipitate was soon formed. The liquid was again filtered, the precipitate washed with a mixture of ether and alcohol, dried and redissolved in 8 c.c. of water. The liquid from each tube was thus treated separately. As checks, the extract from two of the cultures was boiled and to each of the four, 2 cc. of a 5 per cent solution of amygdalin was added. A few drops of chloroform were added to each as an antiseptic. The preparations were then corked and set in a locker in the laboratory. After 
I 8 hours there was an almond odor in the tubes containing the unboiled extract and by the end of 8 hours this odor was very strong. At this time they were tested for reducing sugar and for $\mathrm{HCN}$. Both were present in the tubes containing the unboiled extract while the checks gave no trace of $\mathrm{HCN}$ and only a slight trace of reducing sugar. The other cultures were crushed in a mortar, extracted with 30 per cent alcohol, filtered, and the filtrate treated in the same way that the liquid from the other tubes had been treated. In every case emulsin was found to be present in the unboiled extract.

For comparison with the behavior of Cylindrosporium and its hosts, a Septoria found on leaves of $P$. pennsylvanica was studied. In this case the mycelium passes directly through the host cells and kills the host tissue before fruit bodies are formed. The spots drop . out less frequently than Cylindrosporium spots on the same species. Where they do drop out however there is a separation layer formed in the living tissue just outside the dead tissue. A similar separation layer was also found in leaves of $P$. americana affected with Cercospora. (From herbarium material distributed as Cylindrosporium padi Karst. in Griffith's "West American Fungi" 75a.)

Frank (II) also found that such a callus layer is formed around spots infected by Gnomonia erythrostoma Pers., and Duggar (8) noticed its formation in leaves of Prunus in which "shot hole" was produced by poisonous compounds.

\section{Development of the Perfect Stage}

The perfect or ascigerous stage of the fungus on $P$. avium was found in the spring of I9I I and its development was studied more closely during the winter and spring of I9I2. From the knowledge thus gained it has been comparatively easy to find and follow the development of the perfect stage on the other hosts under observation, especially since trees whose leaves were infected with Cylindrosporium were located during last summer (I912). It has been found on all the hosts under observation except $P$. spinosa, of which only a few leaves were found infected with the conidial stage last summer.

There is considerable variation in the perfect stages found on the

${ }^{6}$ A brief description of the structure and development of the perfect stage of Cylindrosporium on $P$. avium was given in a previous note (I6); but since many points of interest could not be included in a brief note, the entire development will be given in more detail here. 
different host species, but they may be divided into two main groups according to the shape of the ascocarp and its position in the leaf. Since the development varies slightly in the two types, the development on $P$. avium will be described and the others compared with this one.

On this host the production of normal Cylindrosporium conidia (macroconidia) ceases usually early in August, and from this time until after the leaves fall minute conidia (microconidia) about one tenth the length of the macroconidia are formed in great numbers. They are abstricted from the apex of short branched conidiophores (fig. 39) which appear to be the same ones on which the macroconidia were produced earlier. At least they are on the same stroma and in similar positions.

Almost simultaneous with this change in spore form, the stroma begins to develop downward through the mesophyll and palisade layers of the leaf. This growth is at first composed of separate but profusely branched and rather tightly packed threads; but an outer pseudoparenchymatous layer is later differentiated. The host cells are often surrounded by this mycelial growth and often, especially the lignified cells of the vascular bundles, remain so enclosed until the fruit body matures the next spring (figs. 6,8 ). Before the formation of the pseudoparenchymatous covering, coils of densely staining hyphae appear in the stroma. Several of these coils, often six or eight, are formed in each stroma. Each coil consists of two or three turns in the hypha and is made up of several uninucleate cells. Its free end is extended as a trichogyne-like structure, which is also several-celled and slightly enlarged at the apex. This swollen tip extends above the surface of the stroma and ends just above the layer of conidiophores from the apex of which the small conidia (spermatia?) are being abstricted. Soon after leaf-fall the trichogyne-like structures disintegrate and very soon disappear entirely. The fate of the coiled base of this structure is as yet an open question. The dense pseudoparenchymatous covering, which about this time develops entirely around the stroma, makes the inner portion extremely difficult to fix satisfactorily. In material killed November 7 in Flemming's weak osmic acid fixer, the coils show decided signs of degeneration. They are stained scarcely at all by Heidenhain's iron alum haematoxylin, when the surrounding cells are deep black. Also in some of the material killed later no sign of the coils can be seen. On the other hand, 
in some material from the same tree killed December 28 in Carnoy's alcohol acetic acid fixer, many stromata show apparently healthy coils. Later than this they were not seen with certainty.

The pseudoparenchymatous covering of the stroma separates the layer of microconidiophores which now gelatinize and glue the remnants of the epidermal cells to the surface of the stroma. The cells of the pseudoparenchymatous covering as well as the mycelium in the leaf tissue become thick walled and dark colored.

The stroma usually extends entirely through to the upper epidermis, but remains covered both above and below by the leaf epidermis. It is apparent only because of the dark color, and in this condition the fungus passes the winter.

During the first warm days of March the stroma begins to swell toward the lower (dorsal) surface of the leaf, and when sectioned this swelling is seen to be due to a row of erect parallel hyphae which later are seen to be paraphyses. The asci do not appear until about the first of April or later. They develop from branched ascogenous hyphae which arise near the base of the stroma. During the latter part of April and the first of May the asci enlarge rapidly and lift the covering until it finally breaks in a more or less stellate manner. The break occurs before the ascospores are mature, but they mature in a very short time thereafter.

The asci open by a pore in the papillate apex and the spores are shot out. On taking leaves, in which the ascospores are just mature, from a moist chamber, clouds of spores have a few times been seen shot out from the under surface.

After the ascospores are shed the asci and paraphyses disappear, and long slender conidia are formed on short conidiophores which arise apparently as branches from the base of the paraphyses. They are once or twice septate and resemble Cylindrosporium conidia but are usually longer and a little more slender.

Besides being on $P$. avium this type of fruit body and development was found on $P$. pennsylvanica and $P$. cerasus.

In the other type, found on $P$. domestica, $P$. insititia, $P$. virginiana, $P$. serotina and $P$. mahaleb, the stroma develops beneath the lower epidermis and does not extend into the leaf tissue to any appreciable extent. The development is more outward, thus protruding and forming rather prominent disk-shaped to flattened-globose bodies on the under side of the leaf. 
In the leaves of $P$. serotina, $P$. virginiana and $P$. mahaleb the stroma never becomes black but changes to a yellowish brown or to a dull orange color with a waxy appearance when wet. The paraphyses are differentiated much earlier (in January or February) and the ascospores mature slightly earlier. Leaves of $P$. serotina received from Clemson College, S. C., on March I3, bore mature fruit bodies. In leaves from the same tree received in the fall and wintered over in wire cages (Ithaca), they did not mature until about a month later.

On the plum ( $P$. insititia and $P$. domestica) the stromata often turn coal black before the leaves fall. They protrude from the under surface of the leaf and because of the black color are very prominent all during the winter. The spring development is much slower and later than in $P$. virginiana, and slightly later than in $P$. avium. In all other respects the general development as far as observed was similar to that described on $P$. avium.

Infected leaves of all the host species were brought into the laboratory at intervals during the fall and winter. For some reason, however, the fruit bodies refused to develop if brought in before the paraphyses had been differentiated. Perhaps the excessive moisture, or else lack of freezing, prevented the formation of the ascogenous hyphae. It was also noticed that the fruit bodies failed to develop outside when the leaves were packed closely together and therefore moist and poorly aerated, and also when a leaf was folded so that half of its under surface was next the ground the fruit bodies failed to develop on the side in contact with the ground.

When plum leaves were kept very moist in a closed moist chamber the asci did not develop, but conidia were formed instead. This may have been due to the inherent nature of the fruit body, but that it was due to the effect of excessive moisture is more probable. Leaves which had been kept very wet until most of the fruit bodies had developed into conidia-bearing structures, were gradually dried by exposing to the air for a few minutes each day when normal asci and paraphyses developed.

\section{Relation of the Ascigerous Stage to Cylindrosporium}

In order to remove all doubt as to the genetic connection between this ascogenous fungus and the Cylindrosporium which is parasitic on the several host species, several series of inoculations and cross 
inoculations were made during the early spring of 1912 and I9I3. The inoculations were all made in the greenhouse and mostly before the ascospores had developed outside.

Species of Prunus Employed in the Inoculations.-The plants used for inoculating in 1912 were imported seedlings of mazzard ( $P$. avium furnished by the J. B. Stewart Nursery Co.) and small trees of $P$. serotina obtained from a nearby thicket. These were cut back to mere stubs, dipped for a few minutes into a 7 per cent $\mathrm{CuSO}_{4}$ solution, planted in small pots, and set in the greenhouse.

In I9I3 these plants were given the same treatment and used again. About 50 trees each of $P$. virginiana and $P$. pennsylvanica. and I5 of $P$. americana obtained growing wild in this region; 50 mahaleb cherry and 50 myrobalan plum trees furnished by the Greening Nursery Co.; 50 sour cherry (Early Richmond) and 50 peach (Elberta) trees bought from a local nursery; and Ioo plum trees, 25 each of $P$.domestica (several varieties), $P$. americana (several varieties), $P$. hortulana (several varieties), and $P$. insititia, furnished by the Horticultural Department of the Geneva Experiment Station were given the same treatment.

The trees were cut back so as to give vigorous healthy leaves for inoculating and also so they could be covered with bell-jars when this was desirable. They were dipped in the $\mathrm{CuSO}_{4}$ solution to kill any conidia of Cylindrosporium as well as spores of other fungi which might interfere with the results of inoculations, although in so far as Cylindrosporium is concerned sterilization was probably unnecessary, since all observations indicate that the conidia are very short lived and are unlikely to live over winter. None of the plants were ever attacked by Cylindrosporium unless inoculated, although often kept as checks under conditions very favorable for infection had conidia been present.

The plants when used for inoculation had vigorous shoots with usually I2-50 leaves. The myrobalan plums however were so slow in starting that only a few small plants were ready when the last inoculations were made.

Inoculations with Conidia.-The first series of inoculations was made for the purpose of determining the conditions most favorable for infection. Four plants of mazzard cherry were inoculated with a pure culture of Cylindrosporium from the same host species. The conidia were shaken up in a small amount of sterile water which was 
then placed in small droplets on the upper surface of the leaves of one plant, and on the under surface of the leaves of the other three. The former and one of the latter were then covered with bell-jars. Two of those with conidia on the under surface of their leaves were left in the open air of the greenhouse, but moist absorbent cotton was wrapped around the leaves of one plant.

At the end of ten days the plants were examined, when several Cylindrosporium acervuli were found on the two plants under belljars, a few on the plant whose leaves were wrapped with moist cotton, but none on the plant whose leaves were left exposed to the air.

This showed clearly that the leaves must be kept moist for satisfactory infection to occur; so the bell-jar method was used in all later inoculations except where otherwise stated.

In the next series ascospores were used. Ascocarps which had matured on leaves placed in a moist chamber March I6 were on April 4 crushed in a small amount of sterile water which, after being examined microscopically and found to contain quantities of ascospores, was used for inoculating several plants. When examined 7 days later numerous small white specks, which proved to be acervuli of Cylindrosporium, were found on the under side of the leaves.

On April I6 two more plants were inoculated in the same way and at the end of eleven days 45 acervuli were found on their leaves.

To determine whether conidia produced in the ascocarps also served to propagate the fungus, these were used to inoculate some plants. The conidia, if leaves are kept moist after the ascospores are shed, collect in small white clusters on top of the old ascocarps. Several of these clusters were picked up with a needle and distributed in drops of water on sterile glass slides. The water was then examined under the microscope and found to be apparently free from ascospores which can be distinguished by their smaller size and blunt ends. The two plants which were then inoculated with these conidia showed several acervuli at the end of seven days.

Because of the difficulty of obtaining any mycelial growth, no pure cultures were ever obtained from these apothecial conidia from $P$. avium. They frequently germinated in water and in agar but when the germ tubes had reached less than half the length of the spore, growth ceased.

Inoculations with Ascospores.-The ascospores behaved in much the same way. Several hundred cultures were made during the spring 
of I9I I and I9I2 before any growth was obtained. Spores were often found germinating but when transferred to fresh agar, sterilized bean pods, or sterile slices of pear, no further growth occurred. Bean, potato, malt extract, prune, cherry leaf, and plain agar (agar dissolved in tap water), were tried. The plain agar was finally adopted for all germination trials since other fungi and bacteria developed to a much less extent and the ascospores (which germinated more freely than in the other agars) could more often be obtained free from contamination. Finally from a single lot of cultures 37 colonies developed from germinating ascospores transferred, some to tubes of plain agar, others to steamed bean pods and slices of pear.

The growth was very slow. Nearly a month elapsed before any growth could be seen with the unaided eye. The colonies developed as small oval masses similar to those of Cylindrosporium. At first great quantities of conidia were produced, but after about two months conidial production ceased and the stroma turned dark in most of the colonies. Transfers from this stromatic material gave few conidia so that difficulty was experienced in obtaining infections the next winter.

The first inoculations with these pure cultures were made Feb. I, I9I3. A colony from a steamed bean pod was crushed in some sterile water and used to inoculate two plants. After two weeks no infection was found and the same plants were again inoculated this time with spores produced on a very young colony. The drops of liquid left discolored spots where placed on the leaves and after seven days 40 of these spots showed Cylindrosporium acervuli.

Ascocarps were not found on the other species of Prunus until the spring of I9I3; so, although several attempts have been made, no pure cultures have been obtained from them. Successful inoculations have been made with ascospores from leaves of $P$. virginiana, $P$. serotina, $P$. pennsylvanica, $P$. domestica, and $P$. insititia and with a pure culture from apothecial conidia from $P$. insititia infection has been produced on $P$. americana.

In fact the ascospores are more active in producing infection than the conidia of Cylindrosporium. Ascospores from leaves of $P$. virginiana produced abundant infection on plants of $P$. serotina and $P$. virginiana while conidia formed on the $P$. virginiana plants from this inoculation would not cause the disease on $P$. serotina although several plants were inoculated under exactly the same conditions, and abundant infection occurred on a plant of $P$. virginiana inoculated at the 
same time. In like manner the ascospores, but not the Cylindrosporium conidia from $P$. serotina, would infect $P$. virginianum or $P$. mahaleb plants.

Plants of $P$. serotina, $P$. virginiana, and $P$. americana have several times been inoculated with ascospores and conidia from $P$. avium but no infections have ever been obtained from such inoculations. Likewise no infection has ever been produced on $P$. avium by either ascospores or conidia from $P$. virginiana or $P$. serotina.

During the last weeks of April of this year a large series of cross inoculations were made in another greenhouse on all the different species before mentioned; but these resulted in almost total failure, probably because of the low temperature of the house. No infections were obtained except with the organism from $P$. virginiana and $P$. serotina. Only the Cylindrosporium conidia from $P$. virginiana were used and no infections were obtained except on $P$. virginiana where infection was rather abundant. Both ascospores and conidia of $P$. serotina were used. From the conidial inoculations infections occurred on $P$. serotina only. The ascospores however produced infection on $P$. serotina, $P$. virginiana and $P$. mahaleb.

The leaves of $P$. virginiana have also been infected with a pure culture obtained from conidia of the Cylindrosporium on the fruits of the same species. This shows that one species is capable of infecting both leaves and fruit of this host.

\section{Systematic}

The study of morphological and cultural characters of Cylindrosporium from the various host species showed some slight variations, but none which were prominent or consiant enough to be of specific value. It was thought, therefore, before a comparison of the perfect stage from the different hosts was made, that there was but a single species with several more or less distinct forms on these hosts.

Relation of Species of Cylindrosporium to the Natural Subdivisions of Prunus. - A careful study of the ascogenous stage from the different hosts showed that there were marked and constant differences by which the forms might be divided into three distinct groups. The first group includes all those which have the type of development found on $P$. avium (in which the ascocarp extends from one epidermis of the leaf to the other in contrast with those in which the ascocarp is 
only subepidermal). They are distinct in the shape of the ascocarp, its position in the leaf tissue, and in the shape and size of the asci.

Those having the subepidermal ascocarps fall into two distinct groups. On the plums ( $P$. domestica and $P$. insititia) the fruit bodies are coal black with a very decided tendency to be aggregated in clusters, the asci are smaller, more slender than in the other forms, and are almost filled by the spores which are more slender than in either of the other forms.

Contrasted with this we find on $P$. virginiana, $P$. serotina, and $P$. mahaleb the light (yellowish brown to dull orange) colored fruit bodies, larger asci, and apothecial conidia much larger than in the other forms. The covering of the fruit body is composed of more delicate, thinner-walled cells.

After this grouping was made it was found that the hosts of each group fall in the same natural group of the genus Prunus, with the possible exception of $P$. mahaleb. The hosts of the first group are all in the subgenus Cerasus of Engler and Prantl, with flowers in umbels. Those of the second group are plums which are placed in the subgenus Prunophora by the same authors, while those of the third, with the exception of $P$. mahaleb, are placed by them in the subgenus Padus which has the flowers in elongated racemes. $P$. mahaleb has its flowers in a short raceme, and is placed by them in the subgenus Cerasus but in a group separate from the other members of the subgenus. Britton places it in a group with $P$. virginiana and $P$. serotina all having flower clusters terminating branches of the present year's growth.

The results of cross inoculations show a correlation of hosts with characters of the ascogenous stage. In no case has it been found possible to transfer, by inoculations, the fungus from hosts of one group to hosts of another group.

The fact that the hymenium of the ascocarp is surrounded-until nearly mature - by a wall of tissue which finally opens in a stellate manner places all forms of the fungus in the Phacidiales. The relation of the ascocarps to the leaf tissue (covered by the adherent host epidermis), the shape of the asci, and the elongated colorless spores grouped in a fascicle show a distinct relation to Coccomyces in which genus therefore all forms are included. Had only the light-colored form on the Padus group been found there might have been some question as to its relation to this genus, since Coccomyces is said to 
have black ascocarps; but the fact that three forms, so evidently related as those under consideration, show such wide variation in color indicates that the color of the ascocarp is here not a character of generic rank. Because, however, of the morphological and biological differences, before mentioned, the forms are divided into three species, as follows: Coccomyces hiemalis to include the forms on Prunus avium, $P$. cerasus, and $P$. pennsylvanica; Coccomyces prunophorae n. $\mathrm{sp}$. to include the forms on the plums ( $P$. americana, $P$. domestica and $P$. insititia); and Coccomyces lutescens n. sp. to include the forms on $P$. serotina, $P$. virginiana, and $P$. mahaleb. For these species the following characterization is given:

\section{DESCRIPTION OF SPECIES}

Coccomyces hiemalis Higgins, Science, N. S. 37: 637 and 638. 1913. Ascocarps embedded in the tissue of the leaf-usually filling the entire space between the lower and the upper epidermis - both of which usually adhere to the wall of the ascocarp, scattered to"subaggregate, ovate to orbicular, dark brown or black, at first closed but at maturity opening by irregular stellate slits on the under side of the leaves, I25-2IO $\mu$ in diameter; hymenium pale gray to flesh-colored; asci clavate with a long stout pedicellate base, and abruptly papillate apex, 8-spored, 70-95 $\times$ II-I $4 \mu$; paraphyses filiform, septate, apex slightly enlarged, often hooked, often forked; ascospores linear, $33^{-}-50 \times 3 \cdot 5^{-4.5 \mu}$ (the smaller size given in original description was due to a typographical error), continuous or $\mathbf{I}-2$ septate, fascicled in large end of the ascus; apothecial conidia produced on short conidiophores in apothecia after shedding of ascospores, long, slender, $50-80 \times 2.5-4 \mu$, curved, continuous or I-2 septate.

Conidial stage (Cylindrosporium hiemalis): Mycelium intercellular with small haustoria which penetrate the host cells; spots small, brown or reddish brown, sometimes dropping out and producing "shot holes"; acervuli amphigenous or more commonly hypophyllous, subepidermal, finally erumpent exposing the spores; conidia elongate, curved or flexuous, $45^{-65} \times 2.5-4 \mu$, continuous or I-2 septate; microconidia (spermatia?) produced in same acervulus in late summer and fall, small, continuous $4-5 \times 1.5 \mu$.

Conidial stage parasitic in leaves of $P$. avium, $P$. cerasus, and $P$. pennsylvanica. Ascigerous stage saprophytic, appearing the last of April to June, on fallen leaves of the same hosts following the conidial stage.

Latin diagnosis: Ascomatibus hypophyllis sparsis interdum subaggregatis, innatis, punctiformibus, fuscis vel nigris, ovatis vel orbicularibus, $125^{-25} \mu \mu$ lat., primum clausis, deinde in lacinias plures acutas dehiscentibus; disco pallido carneo vel grisea; ascis clavatis crassiuscule stipitatis, $70-90 \times \mathrm{II}-\mathrm{I} 4 \mu$, octosporis, apice papillato; paraphysibus filiformibus, simplicibus aut ramosis, apice recto aut curvato; sporidiis fasciculatis, linearibus $35^{-50} \times 3.5^{-4.5 \mu}$, simplicibus aut I-3 septatis; conidiis in apotheciis filiformibus, flexuosis, $50-80 \times 2.5-4 \mu, \mathrm{I}-2$ septatis.

Hab. In dejectis foliis Prunii avii, $\mathrm{P}$. cerasi, et $\mathrm{P}$. pennsylvanicae. 
Status conidicus: maculis sparsis vel confluentibus, minutis, brunneis aut rufis-brunneis, interdum majusculis dejectis, acervulis solitariis amphigenis, subepidermicis, disciformibus; conidiis filiformibus, flexuosis, denique emergenti-superficialibus, hyalinis $45^{-65} \times 2.5^{-4} \mu$, simplicibus aut I-2 septatis; conidiis minoribus autumno, hyalinis, continuis $4-5 \times \mathrm{I} .5 \mu$.

Hab. In foliis vivis Prunii, $P$. cerasi, et $P$. pennsylvanicae.

Coccomyces prunophorae n. sp. Ascocarps hypophyllous, usually aggregated, subepidermal, erumpent, disk-shaped to subglobose, $125^{-250} \times 100-160 \mu$, black, at first closed but at maturity opening in a stellate manner; hymenium light gray; asci clavate to clyindrical-clavate, $63-87 \times 9-12 \mu$, opening by a pore at the papillate tip; spores slender, straight, curved near the end, $40-60 \times 2.5^{-3.5 \mu}$, at maturity almost filling the asci, continuous or $\mathrm{I}-3$ septate; paraphyses simple or branched, enlarged at apex, septate, about as long as asci; apothecial conidia produced on short conidiophores inside the apothecia, following the asci, usually once septate, $40-60 \times 2.5-3.5 \mu$, resembling ascospores but usually stouter.

Conidial stage (Cylindrosporium prunophorae): mycelium intercellular with haustoria which enter host cells; spots small, brown or reddish brown, sometimes dropping out, producing "shot holes." Acervuli subepidermal, amphigenous, finally breaking through exposing the white mass of spores, conidia elongate, slender, straight or curved, $46-65 \times 3 \cdot 5^{-5} \mu$, usually I-septate; microconidia (spermatia?) found in same acervuli in late summer, small, continuous $4-5 \times 1.5 \mu$.

Conidial stage parasitic in leaves of plums $\left(P\right.$. domestica, $P$. insititia, $P$. americana ${ }^{7}$ and probably $P$. spinosa). Ascigerous stage saprophytic on fallen leaves of the same hosts, May to June, following the conidial stage of the previous summer.

Latin diagnosis: Ascomatibus hypophyllis, aggregatis vel sparsis, subepidermicis, erumpentibus, disciformibus vel subglobosis, $125-250 \times 100-160 \mu$, nigris, primum clausis deinde in lacinias plures acutas dehiscentibus; disco pallido griseo; ascis clavatis vel cylindraceoclavatis, fere sporidiis completis, $63-87 \times 9-12 \mu$, octosporis, apice papillato; paraphysibus filiformibus, simplicibus aut ramosis, septatis; sporidiis fasciculatis, linearibus $40-60 \times 2.5-3.5 \mu$ aut $I-3$ septatis; paraphysibus simplicibus aut continuis ramosis; sporidiis in apotheciis linearibus rectis vel flexuosis, $40-60 \times$ 2.5-3.5 $\mu$, I septatis.

Hab. in dejectis foliis Prunii domesticae, et P. instititiae.

Status conidicus; maculis sparsis, vel confluentibus, brunneis aut rufis-brunneis interdum majusculis dejectis; acervulis solitariis, amphigenis, subepidermicis, disciformibus, conidiis filiformibus, rectis vel flexuosis, denique emergenti-superficialibus, hyalinis, $46-65 \times 3.5^{-5 \mu}$, I septatis, conidiis minoribus autumno hyalinis continuis, $4-5 \times 1.5 \mu$. icanae.

Hab. In foliis vivis Prunii domesticae, $\mathrm{P}$. insititiae, $\mathrm{P}$. spinosae, et $\mathrm{P}$. amer-

Coccomyces lutescens n. sp. Ascocarps hypophyllous, subepidermal, erumpent, disk-shaped to flattened elliptical, $\mathrm{I}_{3} \mathrm{O}-300 \times 7^{0}-\mathrm{I} 5 \mathrm{O} \mu$, often depressed above before maturity, lutescent or dull orange in color, at first closed, then opening in an ir-

${ }^{7}$ Since infection and the Cylindrosporium. acervulus can be produced on $P$. americana by the fungus from $P$. insititia, it is very likely that the perfect stage also develops on this species. 
regularly stellate manner, hymenium grayish to creamy white; asci clavate $70-80 \times$ $1_{4}-19 \mu$, opening by a pore in the papillate apex; spores elongated, fascicled in end of ascus, $40-5 \mathrm{I} \times 3 \cdot 5^{-4} \cdot 5^{\mu}$, continuous or occasionally once or twice septate; paraphyses usually simple though occasionally branched, slightly enlarged at tip, about as long as asci; apothecial conidia very long, $5^{8-87} \times 3.5^{-5} \mu$, once-septate with usually a single vacuole in each cell.

Conidial stage (Cylindrosporium lutescens): spots small, brown to reddish brown, in early summer dropping out from leaves of some species and producing rounded "shot holes"; mycelium intercellular, with haustoria which penetrate the host cells; acervuli subepidermal, amphigenous; conidia exuding in masses or in long tendrils from the break in the host epidermis, long, slender $50-87 \times 3.5-5 \mu$, continuous or I-3 septate, microconidia (spermatia?) produced in the same acervuli in late summer, small, continuous, $4-5 \times \mathrm{I} \mu$.

Conidial stage parasitic in leaves of $P$. serotina and in leaves and fruits of $P$. virginiana, and $P$. mahaleb. Ascigerous stage saprophytic on fallen leaves of the same species in May and June following the conidial stage of the previous summer.

Latin diagnosis: Ascomatibus hypophyllis, sparsis, subepidermicis, erumpentibus, disciformibus, $\mathrm{I} 30-300 \times 70-\mathrm{I} 50 \mu$, luteis vel ferrugineis, primum clausis deinde in lacinias plures acutas dehiscentibus; disco pallido carneo vel griseo; ascis clavatis, crassiuscule stipitatis, $7^{0}-80 \times 14^{-19 \mu}$, octosporis, apice papillato; paraphysibus, filiformibus, simplicibus aut ramosis; sporidiis fasciculatis, linearibus, $35^{-50} \times 3.5^{-4}+5 \mu$, simplicibus aut $\mathbf{I}-3$ septatis; conidiis in apotheciis filiformibus, flexuosis, $50-80 \times 2.5-4 \mu$, I-septatis.

Hab. in dejectis foliis Pruni serotinae, P. virginianae et P. mahalebis.

Status conidicus; maculis sparsis vel confluentibus minutis brunneis aut rufisbrunneis, interdum majusculis dejectis; acervulis solitariis, amphigenis, subepidermicis, disciformibus; conidiis, filiformibus, flexuosis, denique emergenti-superficialibus, hyalinis, continuis $50^{-}-87 \times 3 \cdot 4^{-5 \mu}$, I septatis; conidiis minoribus autumno hyalinis, continuis $4^{-5} \times \mathrm{I} .5$.

Hab. in foliis vivis Prunii serotinae, $P$. virginianae, et $\mathrm{P}$. mahalebis.

\section{General Discussion}

There are many points of interest in the life history and development of the Cylindrosporium on stone fruits, not the least of which is their relation to the host tissue. The parasitic stages of Ascomycetes, other than the Perisporiales which have epiphytic mycelium, usually kill the host tissue outright. In two notable exceptions to this, Gnomonia erythrostoma Pers., and Polystigma rubrum (Pers.) D. C. no haustoria have been found. Haustoria have been described for a large number of the Perisporiales (in the Erysiphaceae by many workers and by Maire (I8) for Meliola ${ }^{8}$ and Asterina). In one of the Erysiphaceae, Oidiopsis taurica Salmon, the mycelium is endophytic, and it is partly so in Phyllactinia corylea (see Palla (2I) Smith (25)

${ }^{8}$ Meliola is placed in the Perisporiales by Saccardo. 
Salmon (24)); but even here the host tissue is not killed. In this respect $\mathrm{Cylindrosporium} \mathrm{resembles} \mathrm{the} \mathrm{last} \mathrm{named} \mathrm{species,} \mathrm{and} \mathrm{the}$ presence of haustoria here is probably related to this behavior.

The formation of spermatia-like bodies in connection with structures which appear to be homologous with the ascogonial branches of the Collemaceae is also very interesting. The function of these bodies is not known. Several attempts to germinate them have always resulted in failure, but considering the difficulty of germinating the normal conidia this is not a very strong argument in favor of their spermatial nature. Their position on the surface of the stroma with the trichogyne of the ascogonium (?) projecting among them would certainly facilitate fertilization, if they do now function or have ever functioned as sexual organs. The most nearly similar arrangement is found in species of Physma. Here there are several ascogonial branches arising in the base of the spermogonium, as in Coccomyces on stone fruits, but passing around the spermogonium to the surface of the thallus. See Stahl (27), Sturgis (28), and others.

The ascogonial structures found in Gnomonia erythrostoma have been studied by Brooks (6) and were not found to function as female sexual organs. On the contrary he thinks the ascogenous hyphae arise from vegetative cells. A similar condition was found in Polystigma rubrum by Blackman and Wellsford (5). From analogy and from the fact that the ascogonial structures appear to disintegrate in many cases, one is led to think that in Coccomyces also the ascogonium does not function as a sexual organ. However the fact that the ascogenous hyphae arise from several points similarly situated in the ascocarp indicates that at least a part of the structure may function as an ascogonium.

\section{Control Measures}

Now that the complete life history of the fungus is known, it should be much easier to devise methods for controlling the disease. Since it lives over winter in the dead leaves it is very important that leaves from trees which are infested with the disease be raked together and burned or buried. If all such diseased leaves are destroyed in and near the cherry orchard there is little danger of the disease appearing the following season in such abundance as to be of a serious nature.

If for any reason destruction of the diseased leaves is not feasible or desirable and one must depend on sprays to keep the disease in check, the spraying should begin early, at least by the middle of May. 
The only common wild species in this region which may harbor the fungus which attacks the sweet and sour cherries is $P$. pennsylvanica.

There appears to be no danger of the disease passing from the wild choke cherry or the wild black cherry ( $P$. serotina) to the sweet or sour cherry; but the fungus from the former may infect nursery seedlings of $P$. mahaleb.

The fungus on the plums has so far been found to infect nothing but plums, but some of the wild plums, certainly $P$. americana, may harbor the fungus.

\section{Conclusions}

I. There are at least three species of Cylindrosporium parasitic on species of the genus Prunus, which in their conidial stage resemble each other very closely. Whether or not Cylindrosporium padi Karst. also occurs in North America is not known; but from the fact that it occurs on $P$. padus, which has racemose flower clusters similar to $P$. serotina and $P$. virginiana, it is perhaps the same as that occurring on the two last named species.

2. The conidial stroma of Cylindrosporium on Prunus develops centrifugally and is never turned up at the edges so as to resemble a pycnidial structure.

3. The mycelium of the species of Cylindrosporium studied is intercellular and obtains its food, in part at least, by means of haustoria which penetrate the host cells. Very often a cellulose sheath is then deposited around the haustorium by the host protoplasm. It seems that no toxin or substance injurious to the host protoplasm is secreted by the fungus, but a few of the host cells are killed probably by drying.

4. "Shot hole" formation in the leaves of the host is apparently correlated with the presence of amygdalin. The amygdalin molecule breaks down into simpler molecules thereby probably increasing the osmotic pressure which causes the cells surrounding the spot to enlarge forming the separation layer.

5. Beside the Cylindrosporium conidia three other spore forms are found in the life cycle of the species studied, viz.: microconidia (spermatia-like bodies), ascospores, and apothecial conidia. All of these except the microconidia are known to propagate the fungus on living leaves. 
6. The microconidia are not produced in pycnidial structures, as reported by Arthur (4) and by Pammel (22), but on the surface of the conidial stroma.

7. While the microconidia (spermatia?) are being formed on the surface of the stroma, ascogonia-like structures are formed with their free end (trichogyne?) projecting above the surface. If these structures do now function or have ever functioned as sexual organs, their formation at the same time and on the same stroma would make fertilization more certain.

8. The fungus passes the winter as a stroma-like body in the fallen leaves, which in the early spring develops into an apothecium of the Phacidiaceous type.

9. That the ascocarps are genetically connected with Cylindrosporium has been shown by their continuous development from the stromata of Cylindrosporium, and by producing infection and Cylindrosporium acervuli in living leaves when inoculated with ascospores from leaves, or with conidia from pure cultures from these ascospores.

IO. The forms of Coccomyces found on the eight species of Prunus fall naturally into three species, one on each of three more or less natural subdivisions of the host genus.

The study on which this article is based has been carried on in the Botanical Laboratory of Cornell University under the direction of Prof. Geo. F. Atkinson, whom I wish to thank for many helpful suggestions and criticisms. Acknowledgments are also due Prof. IV. D. Bancroft for some valuable suggestions, Prof. J. G. Hall for material collected at Clemson College, S. C., the Geneva Agricultural Station, the J. B. Stewart Nursery Co., and the Greening Nursery Co., for plum and cherry trees contributed for experimental purposes.

\section{BIBLIOGRAPHY OF PAPERS CITED}

I. Aderholdt, R. Über die Sprüh- und Dürrfleckenkrankheiten (syn. Schusslockerkrankheiten) des Steinobstes. Landw. Jahrb. 30: 77i-830, pl. I8. I90I.

2. Armstrong, H. E. and E. F. The origin of osmotic effects. III. The function of hormones in stimulating enzymatic change in relation to narcosis and the phenomenon of degeneration and regenerative change in living structures. Proc. Roy. Soc. (London) ser. B. 82: 588-602. I9Io.

3. - The function of hormones in regulating metabolism. Ann. Bot. 25': 507-519. I9II.

4. Arthur, J. C. Plum leaf fungus. N. Y. Agr. Exp. Sta. Rept. 5: 293-298, figs. 6-Io, I886. Idem 6: 347,348 . I 887 . 
5. Blackman, V. H. and Wellsford, E. J. The development of the perithecium of Polystigma rubrum D. C. Ann. Bot. 26: 76I-767, pl. 70, 7I. I9I2.

6. Brooks, F. T. The development of Gnomonia erythrostoma Pers. Ann. Bot. 24: 585-605, pl. 48, 49. I910.

7. Butkewitsch, Wl. Über das Vorkommen eines proteolitischen Enzyms in gekeimten Samen und über seine Wirkung. Zeitschr. f. Physiol. Chem. 32: I-53. I90I.

8. Duggar, B. M. The shot hole effect on the foliage of the genus Prunus. Proc. Soc. Prom. Agr. Sci. 19: 64-69. I 898.

9. Durand, E. J. The differential staining of intercellular mycelium. Phytopathology 1: 129, I30. I9II.

Io. Fischer, M. H. Oedema. Pp. 209, I909 (Reprinted from the "Transactions of the College of Physicians of Philadelphia").

II. Frank, B. Die jetzt-herrschende Krankheit der Süsskirschen im Altenlande. Landw. Jahrb. 16: 4.0I-436, pl. 2. I 887.

I2. Galloway, B. T. A rust and leaf casting of pine leaves. Bot. Gaz. 22: 433-453, p1. 22, 23. I 896 .

I3. Green, J. R. The soluble ferments and fermentation. Sec. ed. I90I.

If. Guignard, L. Sur la localisation dans des Laurier Cerise des principes qui furnissent l'acide yanhydrique. Jour. de Bot. 4: 2I-27, figs. I, 2. I 890.

I5. - Influence de l'anesthesie et du gel sur le dedoublement de certains glucosides chez les plants. Compt. rend. Acad. 'Sci. Paris. 149: I40-I42. 1909.

r6. Higgins, B. B. The perfect stage of Cylindrosporium on Prunus avium. Science N. S. 37:637,638. 1913.

I7. Karsten, P. A. Cylindrosporium padi Karst. (n. sp.). Mycol. Fenn. 16: I59. I884.

I8. Maire, R. Les sucoirs des Meliola et des Asterina. Ann. Myc. 6: I24-I28, figs. I-4. I908.

19. Mann, H. H. The fermentation of tea. Indian Tea Association, pamphlet pp. 22. 1906.

20. Morse, F. W. and Howard, C. D. Poisonous properties of wild cherry leaves. N. H. Agr. Exp. Sta. Bul. 56: I13-123. I 898.

21. Palla, E. Über die Gattung Phyllactinia. Ber. d. Deutsch. Bot. Ges. 17: 6472, pl. 5. I 1899 .

22. Pammel, L. H. Spot disease of cherries. Iowa Agr. Exp. Sta. Bul. 13: 55-66. I89I.

23. Peck, Chas. H. Cylindrosporium padi Karst. Rep. State Botanist, State of N. Y. 48: I5. I 895 .

24. Salmon, E. S. Preliminary note on an endophytic species of the Erysiphaceae. Ann. Mycol. 3: 82, 83. 1905.

25. Smith, Grant. The haustoria of the Erysipheae. Bot. Gaz. 29: I53-I84, pls. II, I2. 1900 .

26. Sorauer, P. Pflanzenkrankheiten, third ed. 2: 1908.

27. Stahl, E. Beiträge zur Entwickelungsgeschichte der Flechten, pt. I, pp. 55, pls. I-4. 1877 . 
28. Sturgis, W. C. On the carpological structure and development of the Collemaceae and allied groups. Proc. Amer. Acad. Arts and Sci. 25: 15-52, pls. I-8. I 890 .

29. Vines, S. H. Tryptophane in proteolysis. Ann. Bot. 16: I-22. 1902.

30. Wehmer, C. Pflanzenstoff. (Phanerogamen). I9II.

\section{DESCRIPTION OF PLATES XIII-XIV}

\section{Plate Xili}

FIG. x. Photograph of leaf of Prunus avium with ascocarps, magnified about 2 diameters.

FIG. 2. Photograph of a portion of same leaf showing ascocarps opening by stellate slits, magnified about 6 diameters.

In the following three plates the figures are from camera lucida drawings and the magnification is indicated after each figure.

\section{Plate XIV}

FIG. 3. Section of leaf of Prunus avium showing the subepidermal acervulus bearing microconidia (spermatia?) while still covered with macroconidia of Cylindrosporium. $\times 250$.

FIG. 4. Pycnidium of Septoria pruni Ellis in leaf of Prunus americana, from "North American Fungi" II, II 5 I. X I,300.

FIg. 5. Section of leaf of Prunus serotina showing subepidermal conidia bearing acervulus of Septoria cerasina Peck (= Cylindrosporium), from type material. $\times 250$.

FIG. 6. Ascocarp of Coccomyces hiemalis in leaf of Prunus avium, showing remains of epidermal cells above and below and lignified cells of host vascular bundle near center of ascocarp. $\times 250$.

Fig. 7. Ascocarp of Coccomyces prunophorae. $\times 250$.

FIG. 8. Young ascocarp of Coccomyces hiemalis in leaf of Prunus avium showing portions of three ascogonial (?) coils and two trichogynes. The pseudoparencyhmatous covering of the ascocarp is beginning to form and conidiophores (microconidiophores) are beginning to disintegrate above the center of the young fruit body. $\times 250$.

FIG. 9. Coiled ascogonial (?) branch from a slightly later stage in which the trichogyne is disintegrating.

FIG. 10. Young asci and portions of ascogenous hyphae from a section of developing ascocarp of Coccomyces hiemalis.

FIG. II. Old ascocarp of Coccomyces hiemalis producing "apothecial conidia." $\times 250$.

\section{Plate XV}

FIG. I2. Section of leaf of Prunus virginiana showing entrance of germ tube of Cylindrosporium spore through a stoma and subsequent growth of mycelium. From artificial infection under bell jar four days after inoculation. $\times 45^{\circ}$.

FIG. I3. Early stage in the development of stroma and acervulus of Cylindrosporium beneath the upper epidermis of same host, five days after inoculation. Two haustoria have entered an epidermal cell. $\times 450$. 
FIG. I4. Section of leaf of Prunus virginiana showing amphigenous nature of Cylindrosporium acervuli and the separation of the diseased spot. $\times 47$.

FIG. I5. Portion of section similar to fig. I4 more highly magnified showing the enlarged cells of separation layer and walls of ruptured cells. $\times 45^{\circ}$.

FIG. 16. Later stage, showing the suberized layer (the cell walls of which are represented by heavier lines) and the remains of the enlarged cells now dead. $\times 450$.

FIG. 17. Young haustoria, showing nuclei and vacuoles, in cells of bundle sheath in leaves of Prunus virginiana.

FIG. I8. Haustoria in mesophyll cell of the same leaf surrounded by cellulose sheaths.

FIG. 19. Developing ascocarp of Coccomyces lutescens in leaf of P. virginiana, showing the subepidermal position with remains of the gelatinized conidiophores and the early appearance of the paraphyses. $\times 250$.

FIG. 20. Mature ascocarp of same with asci and paraphyses. $\quad \times 250$.

FIG. 2I. Developing ascocarp of Coccomyces lutescens on Prunus serotina still covered by host epidermis. $\times 250$.

FIG. 22. Mature ascocarp of same. $\times 250$.

\section{Plate XVI}

FIG. 23. Asci and single paraphysis of Coccomyces hiemalis from Prunus avium. $\times 450$.

FIG. 24. Ascospores of same more highly magnified. $\times 625$.

FIG. 25. Ascospores of same germinating in an agar culture five days old.

FIG. 26. Asci and paraphyses of Coccomyces hiemalis from Prunus pennsylvanica, spores are mature in one on left. $\times 45^{\circ}$.

FIG. 27. Conidia (Cylindrosporium) of Coccomyces hiemalis on Prunus pennsylvanica. $\times 450$.

FIG. 28. Asci and paraphysis of Coccomyces hiemalis on Prunus cerasus. The spores have been shed from one of the asci, and are scarcely mature in other. $\times 450$.

FIG. 29. Germinating conidia (Cylindrosporium) of Coccomyces hiemalis. $\times 450$.

FIG. 30. Microconidia (spermatia?) and microconidiophores of Coccomyces hiemalis from $\mathrm{P}$. avium. $\times 450$.

FIG. 31. Apothecial conidia of Coccomyces hiemalis on P. avium. $\quad \times 450$.

FIG. 32. Same germinating after two days in water culture.

FIG. 33. Asci and paraphyses of Coccomyces prunophorae from P. domestica. $\times 450$.

FIG. 34. Ascospores from same more highly magnified. $\times 650$.

FIG. 35. Apothecial conidia of Coccomyces prunophorae. $\times 450$.

FIG. 36. Conidia (Cylindrosporium) of Coccomyces prunophorae. $\times 450$.

FIG. 37. Ascus of Coccomyces lutescens from Prunus mahaleb.

FIG. 38. Ascospores of same more highly magnified. $\times 625$.

FIG. 39. Microconidia and microconidiophores of Coccomyces lutescens. $\times 450$. 

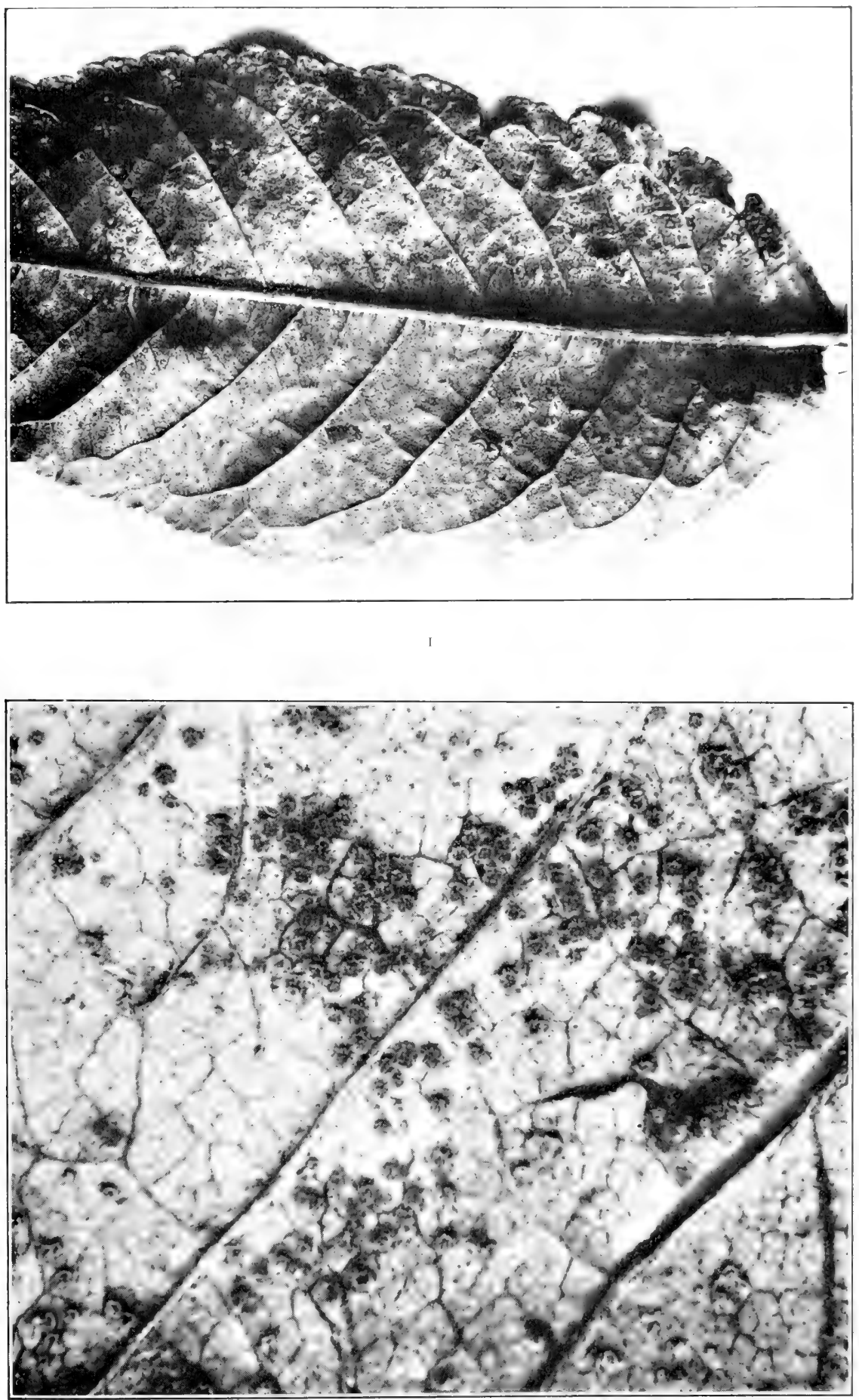





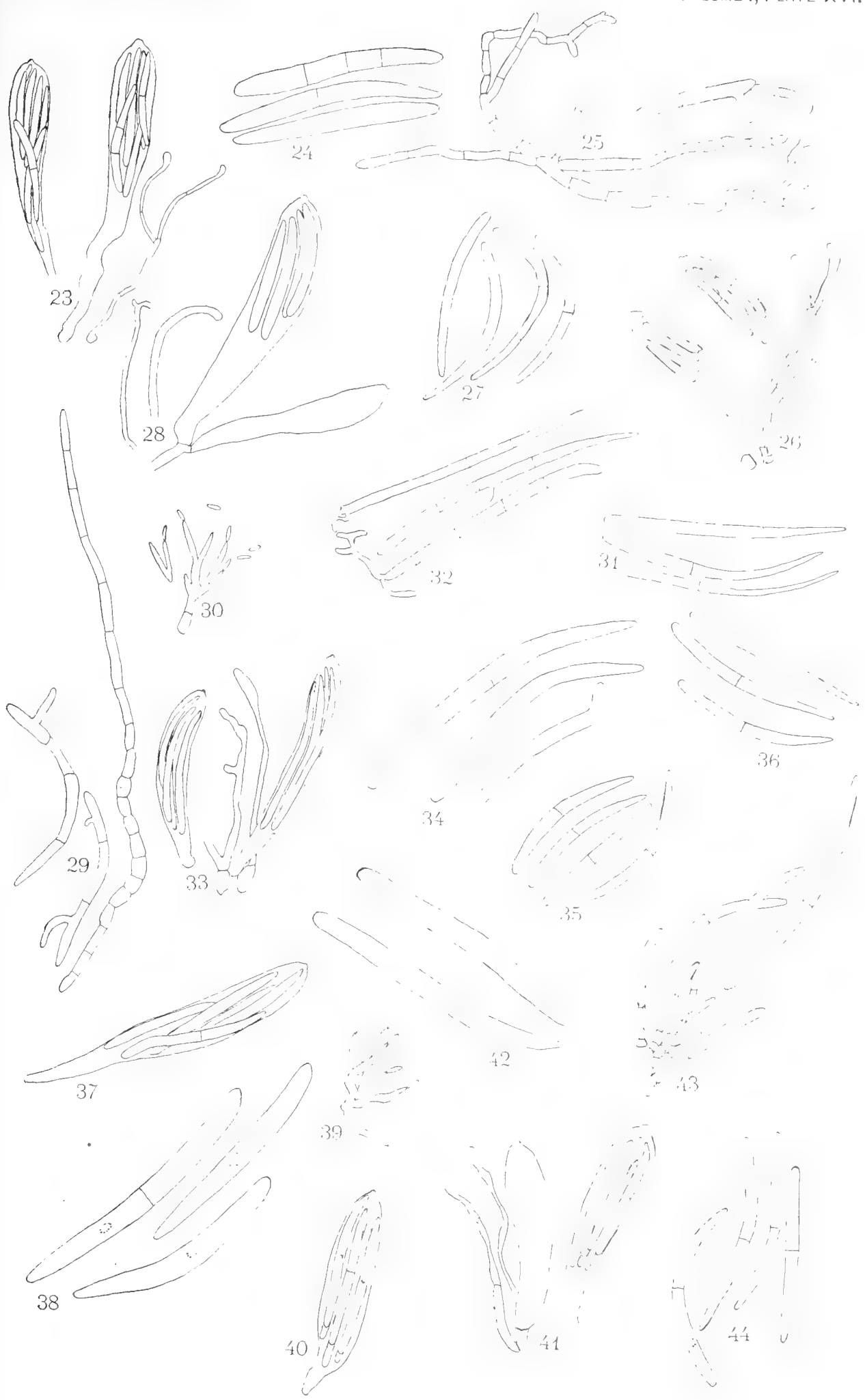

Higgins: LifE History OF ('ylindrospority. 

FIG. 40. Ascus of Coccomyces lutescens from P. virginiana.

FIG. 4I. Asci and paraphyses of Coccomyces lutescens from Prunus scrotina. $\times 450$.

FIG. 42. Ascospores of same more highly magnified. $\times 625$.

FIG. 43. Apothecial conidia and conidiophores of Coccomyces lutescens on Prunus serotina.

FIG. 44. Conidia (Cylindrosporium) of Coccomyces lutescens on Prunus serotina. 



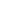




\section{(x)} 3. $\rightarrow x, 5$

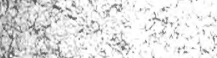


